\title{
PERSPECTIVE
}

\section{Do CRISPR Germline Ethics Statements Cut It?}

\author{
Carolyn Brokowski
}

\begin{abstract}
The extraordinary wave of genomic-engineering innovation, driven by CRISPR-Cas9, has sparked worldwide scientific and ethical uncertainty. Great concern has arisen across the globe about whether heritable genome editing should be permissible in humans - that is, whether it is morally acceptable to modify genomic material such that the "edit" is transferable to future generations. Here I examine 61 ethics statements released by the international community within the past 3 years about this controversial issue and consider the statements' overarching positions and limitations. Despite their inability to fully address all important considerations, many of the statements may advance debate and national and international law and public policy.
\end{abstract}

\section{Introduction}

In February 2017, the United States National Academies of Sciences, Engineering, and Medicine (NASEM) Committee on Human Gene Editing published an expansive report $^{1}$ reviewing scientific, ethical (moral), and legal concerns about the astonishing rise of genomic engineering technology. The NASEM committee, chaired by Massachusetts Institute of Technology/Howard Hughes Medical Institute molecular biologist Rick Hynes and University of Wisconsin bioethicist Alta Charo, assembled 22 international experts from the fields of biomedicine, law, and bioethics. The report's chief conclusion, surprising to some, was that heritable genome editing*the modification of the germline with the aim of generating a new human being who could therefore transfer the genomic change to future generations-should be impermissible now ${ }^{2}$ but eventually could be justified for certain medical indications. However, the NASEM committee did not sanction the use of CRISPR ${ }^{\dagger}$ for any form of enhancement. Currently, it is unlawful for U.S. federal funds to be used to create, destroy, or modify human embryos to include heritable genetic changes for research purposes. ${ }^{3-5}$ Yet the NASEM report's conclusion implies that once safety risks are better understood, then clinical trials conceivably could commence.

*Techniques involving mitochondrial replacement therapy are beyond the scope of this discussion, despite potential for overlapping medical ethics' concerns. Clustered Regularly Interspaced Short Palindromic Repeats.
Safety, risk/benefit, and efficacy concerns are familiar territory in the context of somatic genome editing - the modification of nonreproductive cells such as cardiomyocytes, monocytes, and osteoblasts. Human gene therapy, for example, which arose during the 1980s and 1990s, involves the application of nucleic acid sequences or genetically engineered organisms for investigational and/or therapeutic purposes. In 1999, Jesse Gelsinger, an 18year-old diagnosed with ornithine transcarbamylase deficiency, a rare recessive X-linked disorder, died in a phase-1 dose-escalation clinical trial. Though controversial, many attribute his death to a massive immune response against the high-dose adenoviral vectors administered during the research. Today the risks in gene therapy trials are better understood, ${ }^{6,7}$ although safety, efficacy, and other ethical matters remain unresolved. Still, many gene therapy trials are underway, including some using more traditional forms of gene editing such as zinc finger nucleases. ${ }^{8}$ The rapid emergence of CRISPR gene editing technology, however, has significantly intensified the need for scientific, medical, and ethical evaluation of the potential benefits and risks of gene editing. Given the pace of scientific discovery in this field and early reports on the deployment of CRISPR gene editing in human embryos, it is not too soon to ask whether it is morally acceptable to modify the human germline using this approach. As of March 2018, three groups have published studies involving human germline editing. ${ }^{9-11}$ Two reports arose from

Department of Emergency Medicine, Yale School of Medicine, New Haven, Connecticut.

Address correspondence to: Carolyn Brokowski, Department of Emergency Medicine, Yale School of Medicine, 464 Congress Avenue, New Haven, CT 06519-1362, E-mail: Carolyn.Brokowski@yale.edu

(c) Carolyn Brokowski 2018; Published by Mary Ann Liebert, Inc. This Open Access article is distributed under the terms of the Creative Commons License (http:// creativecommons.org/licenses/by/4.0), which permits unrestricted use, distribution, and reproduction in any medium, provided the original work is properly cited. 
groups in China and were followed by a major study from Shoukrat Mitalipov and colleagues in Nature in August 2017, which reported the successful correction of a defective gene in human embryos. ${ }^{9}$

Not surprisingly, the international community's views about gene editing for clinical purposes, and especially the possibility of germline editing, vary enormously. At least 61 ethics reports and statements ${ }^{*}$ have been crafted by more than 50 countries and organizations over the past 3 years (Table $1^{1,12-73}$; Fig. 1). Statements have been published by U.S. and international scientific societies such as the American and European Societies of Human Genetics, the European Society of Human Reproduction and Embryology, and the International Society for Stem Cell Research; bioethics organizations including the Nuffield Council in the United Kingdom, the Danish Council on Ethics, and the International Bioethics Committee of the United Nations Educational, Scientific and Cultural Organization; industry groups and organizations including the Biotechnology Innovation Organization and various genome-editing biotech companies; and political groups such as the 2015 White House.

Although these statements vary considerably in both length and depth of analysis, they provide a large body of scholarship in which to frame and discuss the medical and moral permissibility of heritable genome engineering. Most statements were produced by organizations from Europe and the United States, though groups from Canada, Latin America, New Zealand, Japan, China, Australia, and other international conglomerates also contributed (Table 1). From a bioethics or legal perspective, many of these reports are limited. However, some of the questions raised and debated provide a preliminary basis for addressing key critical issues and advancing international law and public policy in this arena.

\section{Take Your Positions}

Statements' positions range widely-from being direct, pithy, and practical to expansive, indeterminate, nuanced, and philosophical. They also capture a variety of important issues (Fig. 2). Few groups were willing to go as far as the NASEM Committee in tentatively supporting germline editing, even under certain specified conditions. Most statements were expressly against heritable genome editing at the current time (Table 1; Fig. 3). ${ }^{1,15-18,20-26,28,30,31,33,34,37-39,41,42,44,45,47,50,57,60-68,70-73}$ Some favor a form of moratorium-ranging from broadly prohibiting "gene editing of human embryos or gametes which would result in the modification of the human genome" 34 to more narrowly prohibiting "attempts to

The selection of reports and statements presented herein is not exhaustive but does represent a sizeable sample of those published to date. apply nuclear genome editing of the human germ line in clinical practice." ${ }^{44}$ Accordingly, various categories of risk outweigh any potential benefits for now. Overall, much of the international community seems reluctant to proceed with heritable germline editing.

A common concern is that editing might pose technical/mechanical obstacles, leading indefinitely to safety risks in the modified organism and future progeny. ${ }^{1,12-19,21-37,39-54,56,58,61,63-68,71,72}$ Obstacles might include inaccurate editing (off- and on-target effects), incomplete editing (mosaicism), efficiency challenges (success rate), and interference from unexpected and/ or poorly understood factors (e.g., epigenetic, immune, and environmental events; pleiotropy; and penetrance) resulting in unintended consequences.

Further, in a joint position statement, the American Society of Gene \& Cell Therapy and the Japan Society of Gene Therapy ${ }^{\S}$ noted that " $[\mathrm{t}]$ he requirement that the results of an experiment be susceptible to analysis and characterization before further applications are undertaken cannot be met with human germ-line modification with current methods, because the results of any such manipulation could not be analyzed or understood for decades or generations-a situation incompatible with ethical imperatives and with the scientific method." 37 Other concerns included the potential return of eugenics, human enhancement, and the exacerbation of social inequalities, along with a purported lack of "compelling medical rationale" justifying such interventions. Additionally, difficulties with obtaining informed consent, ${ }^{1,15,16,21,28,30,43,48-50,54-56,70}$ given the complexity surrounding the status of the human embryo and the potential effects lasting into numerous future generations, were highlighted. Many also point out that national and international laws already prohibit such modifications.

Several other groups assume more moderate positions. For instance, the 2017 joint report issued by the Netherlands Commission on Genetic Modification and the Health Council of the Netherlands maintains that, due to the limited knowledge about risk and possible clinical applications and benefits at this time, it is "not possible to come to a clear and definite conclusion about the acceptability of germline modification, but it is possible to investigate the conditions under which clinical applications of germline modification could be practised." 46 Therapeutic applications of germline modification could be permissible, and the report states that healthcare providers might even have a moral obligation to make available this option, if safety and efficacy concerns are alleviated.

Despite its opposition to heritable germline editing at the current time, the NASEM report reached a similar

\footnotetext{
'This group is now entitled the "Japan Society of Gene and Cell Therapy."
} 


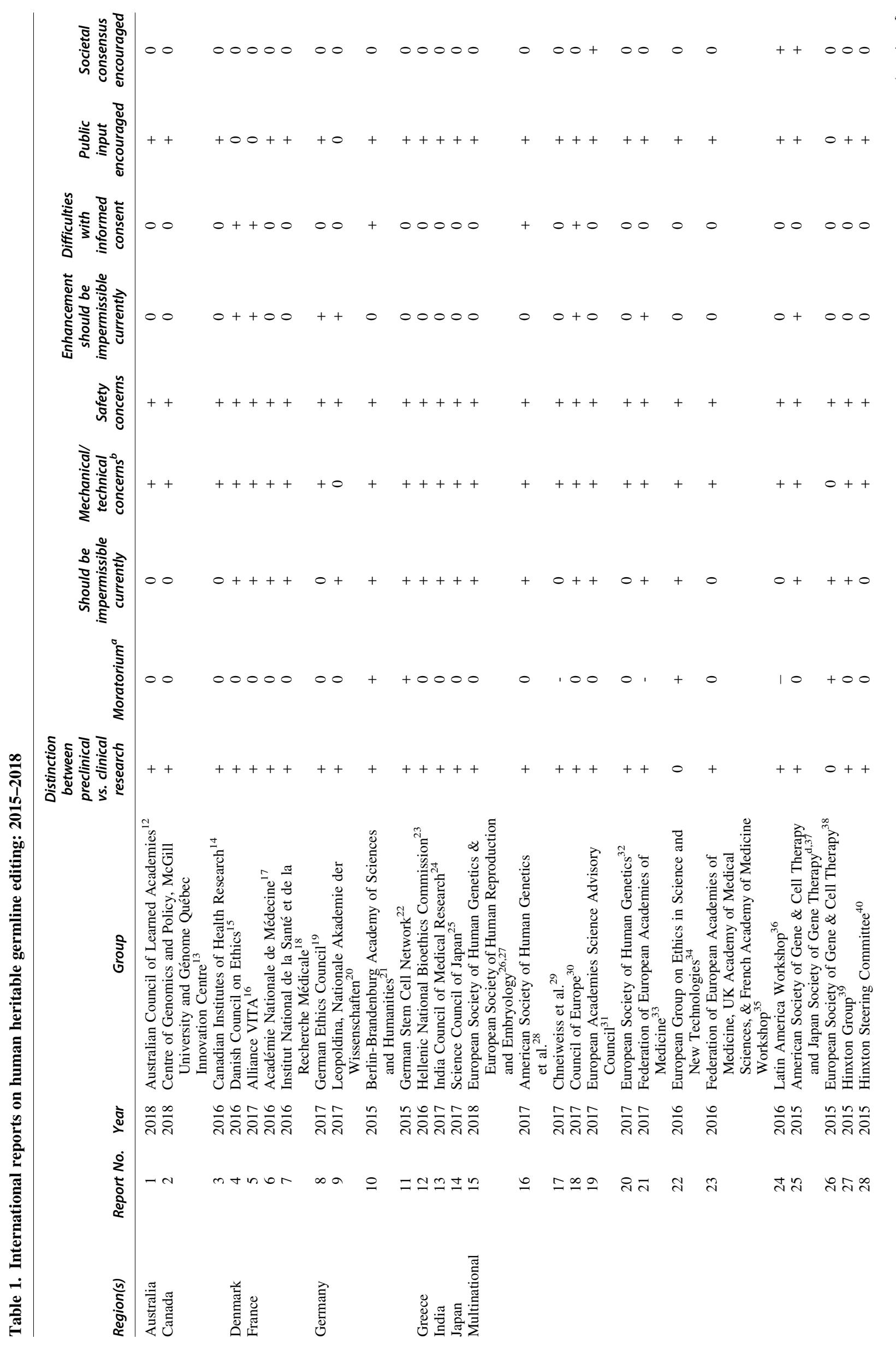




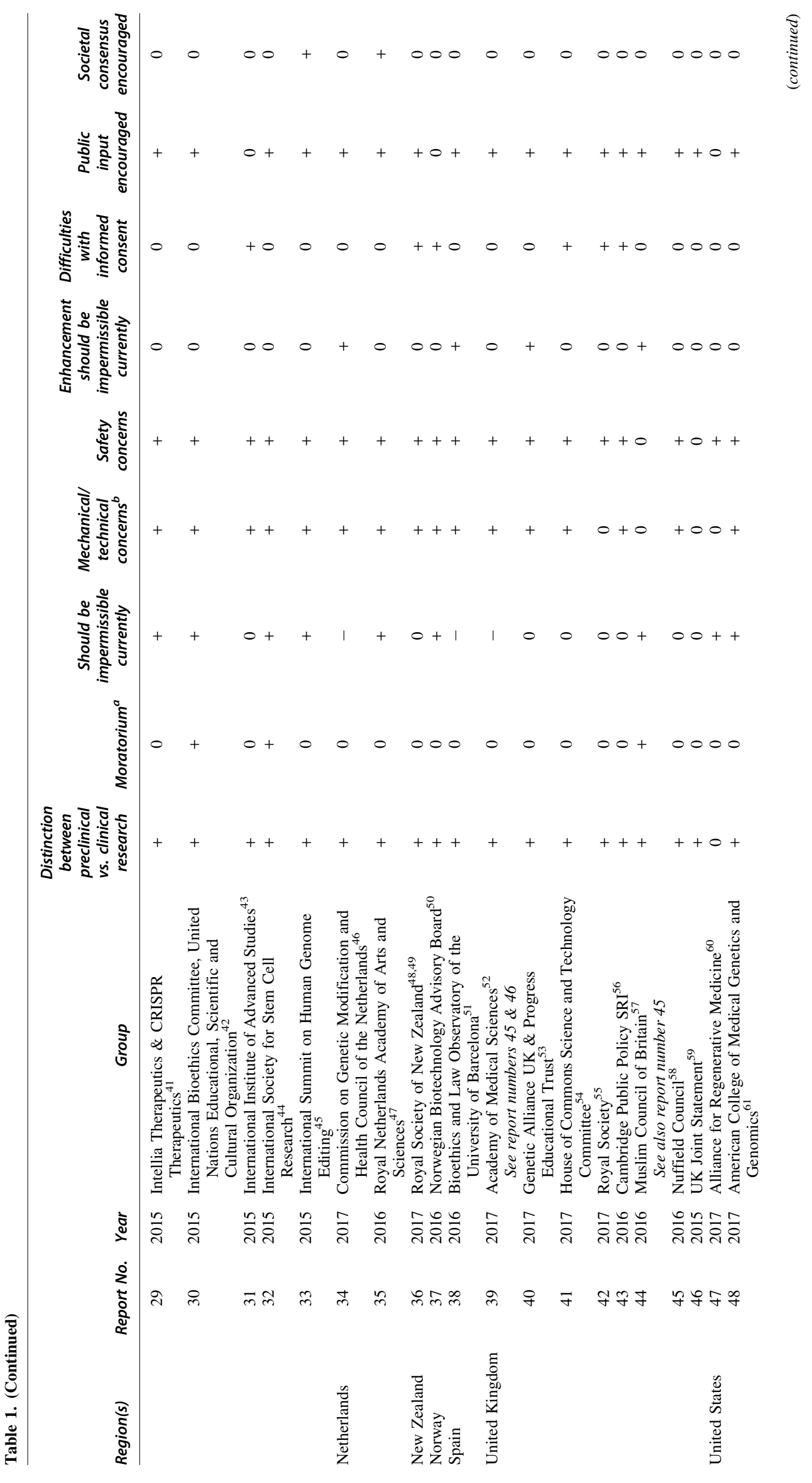




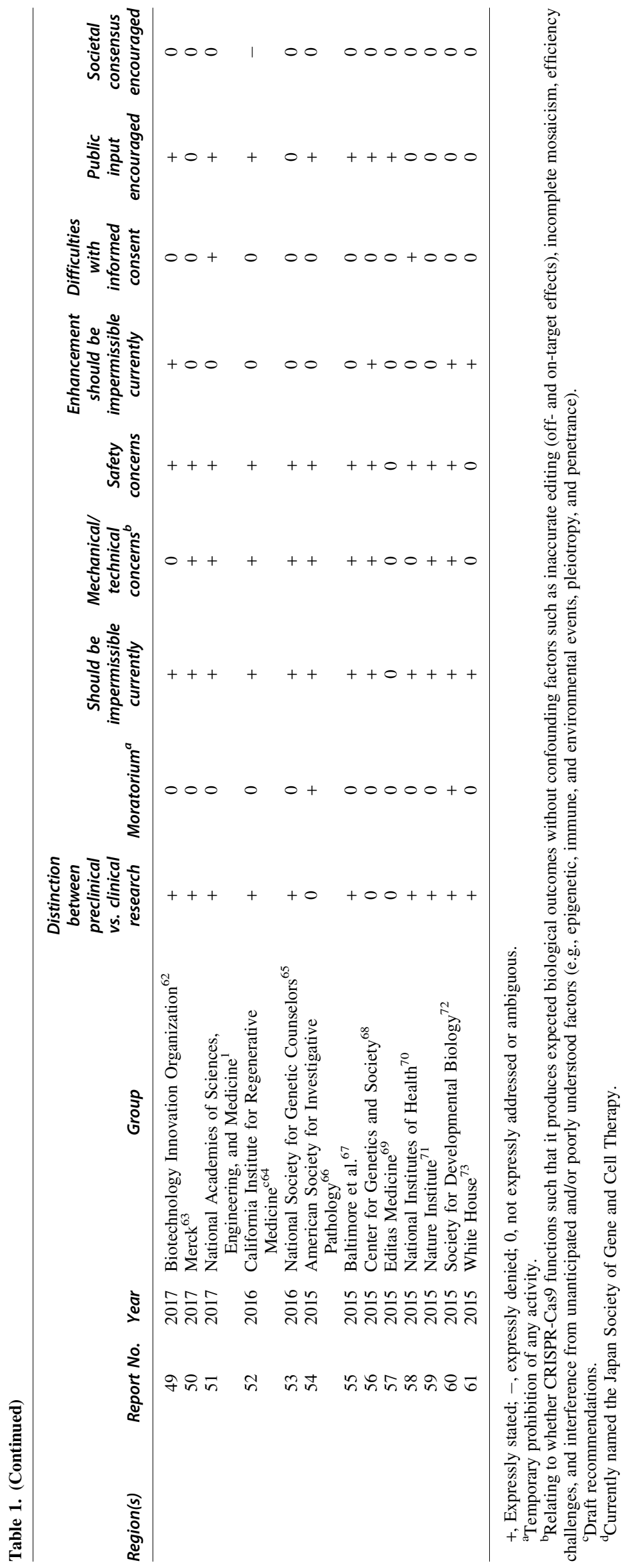




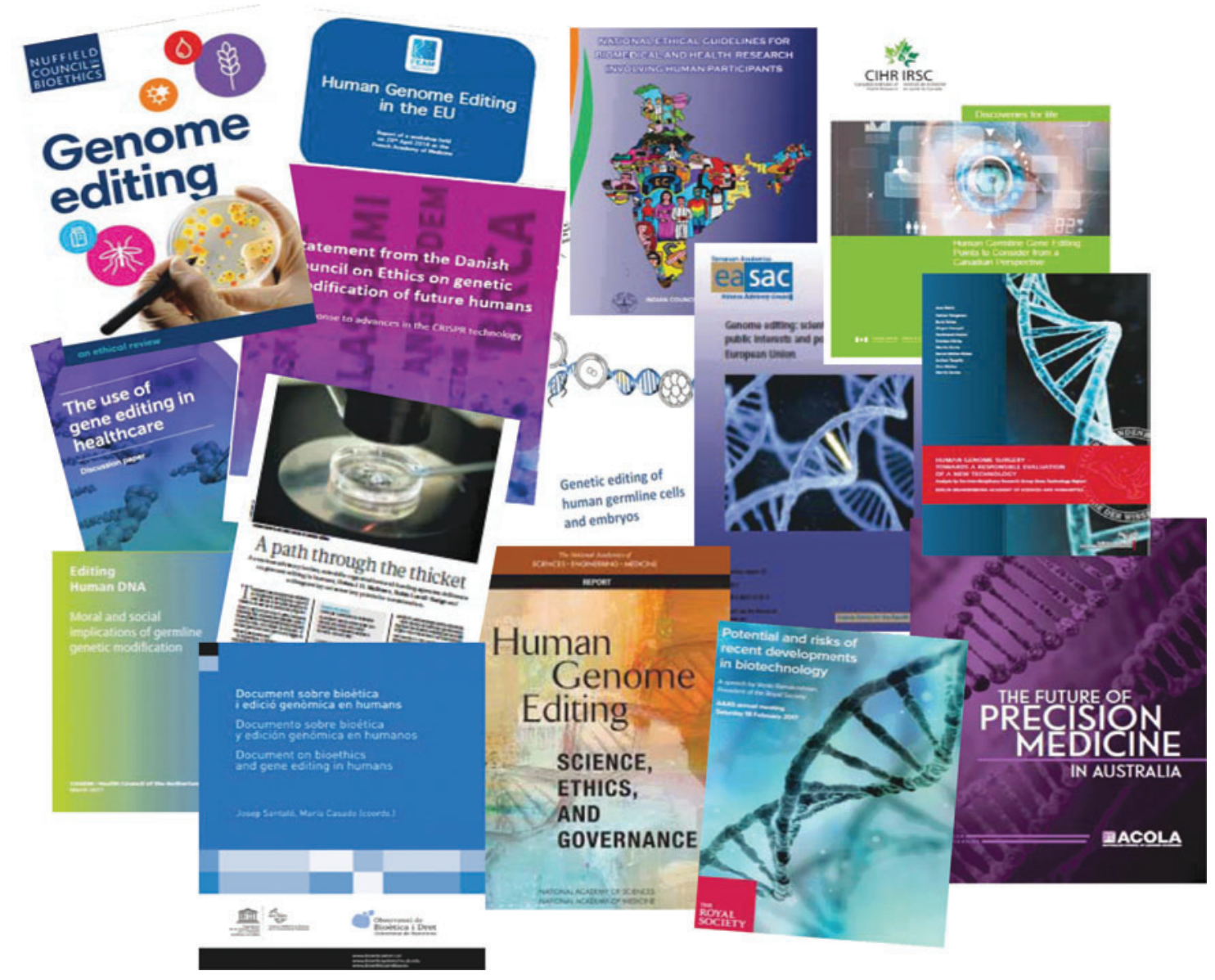

FIG. 1. Cover Story: More than 60 official reports and statements about the ethics of germline editing have been published within the past three years.

conditional conclusion, ${ }^{1}$ noting that trials would be acceptable if technical challenges of the research were resolved, the risk/benefit ratio of the proposed research were reasonable, and a "robust and effective regulatory framework" were established that would include the following:

(1) No reasonable alternatives to the trial exist;

(2) The goal of the research is to prevent a serious disease or condition;

(3) The research focuses only on editing genes that seem to predispose or cause the disease or condition;

(4) Gene conversion is limited to only those versions associated with ordinary health and that are unlikely to cause adverse effects;

(5) Credible preclinical and clinical health risk data are available;

(6) Institutions establish both ongoing monitoring of the health and safety of clinical research participants;

(7) Long-term follow-up plans are defined and implemented;

(8) Transparency and privacy protections are in place;
(9) Societal risks are controlled; and

(10) Mechanisms inhibit extension to uses other than preventing a serious disease or condition.

The biggest international gathering so far on the subjects of CRISPR and germline editing took place in Washington, DC in December 2015. NASEM, the Chinese Academy of Sciences, and the U.K.'s Royal Society co-hosted the International Summit on Human Gene Editing, which was co-organized by Jennifer Doudna and chaired by David Baltimore. One of the major conclusions of this meeting was that allowing heritable genome editing would be "irresponsible" unless and until more were known about safety, risks, benefits, and efficacy and "broad societal consensus" were achieved. ${ }^{45}$ Since then, however, as noted by the German Ethics Council, there seems to have been a subtle, though important, shift in opinion about the permissibility of heritable genome editing - from "impermissible as long as risks have not been determined" to "permissible if risks are accurately determined." 19 


\section{Clinical Ethics}

- "The EGE cautions against reducing the debate to safety issues and the potential health risks or health benefits of gene editing technologies. Other ethical principles such as human dignity, justice, equity, proportionality and autonomy are clearly at stake and should be part of this necessary reflection towards the international governance of gene editing." (34)

- "Participants wanted the freedom to reach their own moral conclusions. They were open to arguments from different moral perspectives but they did not want such perspectives to be presented as though they were unassailable facts, and they did not want such perspectives to be placed on an equal footing with factual explanations of the science of genome editing." (53)

- "... benefits from any genetic modification must be shared equally across society. Any treatment that would exacerbate health inequalities would be in conflict with Islamic bioethical principles." (57)

- “... ethical concerns specific to germline modifications involve potential irrevocable and unforeseen risks for future generations; the preservation of human diversity and individuality; the respect for reproductive freedom and autonomy; and the protection of the wellbeing of children born of the technology (i.e. best interests)." (13)

\section{Enhancement}

- "The impact of social and health inequality regarding access to potentially enhance the genetics of future generations needs to be considered to prevent uses which reinforce prejudice and worsen inequalities within and between societies." (49)

- "Permitting germline intervention for any intended purpose would open the door to an era of high-tech consumer eugenics in which affluent parents seek to choose socially preferred qualities for their children. At a time when economic inequality is surging worldwide, heritable genetic modification could inscribe new forms of inequality and discrimination onto the human genome." (68)

- "... genome editing techniques should proceed in phases: permitting basic research, approving therapeutic use in somatic cells, evaluating the possibility of approving germ line therapy in certain cases, while stopping its use for so-called human enhancement (biological enhancement).' (51)

\section{Regulation}

- "The system for the evaluation and control of research must be truly effective; thus, ethics committees and other existing guarantees must really serve to evaluate the scientific and methodological implications of the research, as well as its ethical, legal and social implications." (51)

- "There is also the question of how much to value the judgments of members of the general public, who do not necessarily possess sufficient knowledge about the technology. Citizens' consensus is important for democracy, but it is also necessary for specialists to explore the issues and present options. It is important to reconcile the views of specialists and the public." (43)

\section{Philosophy}

- "... sometimes it is difficult to draw a sharp line between diseases and the outer limits of normal. Consider this: Is it a disease having protruding ears or being very short? While this is debatable, we nonetheless treat both conditions in hospitals. The boundaries of disease are not fixed. They are continuously being drawn and redrawn in different cultures with different opportunities for treatment." (15)

- " $\ldots$ the responsibility to future generations is important because it respects the rights of those coming into life later on. It is also important for our social relationships, for a society in solidarity and for justice between all peoples to keep in mind that the respect for the dignity of every human being entails the duty to refrain from making her or him a mere instrument for the fulfilment of the wishes and preferences of others." (42)

- "The implementation of heritable human genetic modification - often referred to as the creation of "genetically modified humans' or 'designer babies' - could irrevocably alter the nature of the human species and society." (68)

FIG. 2. Bioethics considerations. Extracts from some selected reports on genome editing illustrate a diversity of opinions on some key bioethical issues. 


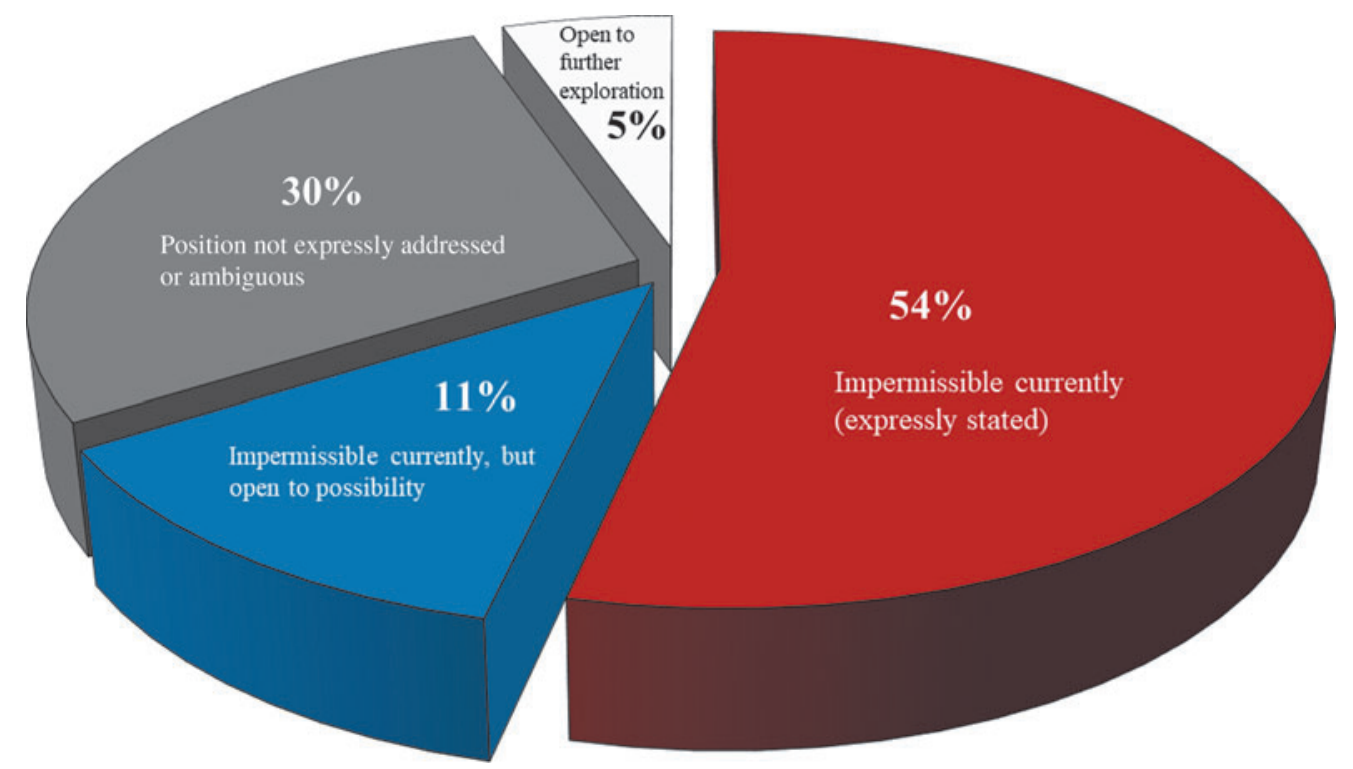

FIG. 3. Opinions on the moral permissibility of heritable genome editing. This pie chart displays the views of 61 ethics reports on germline editing. The views represented are not logically exhaustive. The majority (54\%) expressly considered germline editing impermissible at the current time. ${ }^{16-18,20-22,24,25,28,30,31,33,34,37,38,41,42,44,50,57,60-68,70-73}$ A further $11 \%$ also consider germline editing impermissible currently, but are expressly open to the possibility of allowing it under certain conditions. ${ }^{1,15,23,26,39,45,47}$ In $30 \%$ of cases, the position is not expressly addressed or is ambiguous. ${ }^{12-14,19,29,32,35,36,40,43,48,49,53-56,58,59,69}$ And 5\% of the reports state an openness to further exploration. ${ }^{46,51,52}$

Finally, although recognizing potential difficulties, a statement from the U.K.'s Academy of Medical Sciences, written in response to the Nuffield Council on Bioethics' report, ${ }^{58}$ is one of the few documents expressly favoring the use of this application in the future, "provided [its] introduction is based on a strong evidence base, is in line with societal values, and is informed and supported by active engagement with patients and the public." 52 Despite its encouraging spirit, the statement cautions that heritable applications must be crafted according to "societal values, and be supported by active engagement with patients and the public to effectively communicate the conditions in which genome editing can, and cannot, be helpful.",52

\section{Limitations, Utility, and Future Directions}

The international community's fast response to calls for broad discussion ${ }^{67}$ about germline editing is laudable. Yet for all of the earnest deliberations and valuable reports issued since 2015, there are many nagging limitations. Some statements offer conclusions but lack significant support. The Alliance for Regenerative Medicine, for instance, notes that "Patients will benefit more immediately from resources being directed towards somatic applications of the technologies at this time, as most genetic diseases manifest in and can be treated in somatic, not germline, cells." ${ }^{60}$ It goes on to conclude that "heritable germline editing is not ready to be tried in humans." Yet widespread experimentation would be required to determine whether somatic or germline editing would yield more value. As many countries outlaw or at least fail to fund such research, there is simply a dearth of robust, reliable data to ascertain potential benefits and risks of germline editing-thereby confounding the ability of the moral permissibility of experimentation.

Second, sometimes purported justifications are questionable. For instance, National Institutes of Health (NIH) Director Francis Collins is staunchly opposed to germline editing in any form. He cites as problematic "unquantifiable safety issues, ethical issues presented by altering the germline in a way that affects the next generation without their consent, and a current lack of compelling medical applications justifying the use of CRISPR/ Cas9 in embryos."70 Should "unquantifiable safety issues" prohibit U.S. federal funding, by the NIH and other federal agencies, of all heritable germline clinical trials? The purpose of many trials, after all, is to assess safety. Does not the promotion of procreative liberty, through correcting genetic defects in potentially unhealthy embryos ${ }^{74}$ count as a "compelling medical application"? Ultimately, Collins might be correct in his conclusion, but additional, specific analysis would help to illuminate and justify this opposition. Further, why concede that consent complexities and alleged lack of compelling medical justification should trump the potential 
benefits of heritable genome experimentation, such as potentially promoting the health of defective embryos and facilitating procreative liberty? In addition, the NIH director cites "existing legislative and regulatory prohibitions" against heritable genome editing. Yet even if there are (or were) good reasons for this legislation, the justificatory weight of the laws as presented is question begging.

Third, despite the wealth of topics about heritable genome editing considered in these $60+$ reports, important questions arise about how to move forward. For example, even the NASEM report does not expressly show why or how the conditions under which heritable genome editing might be justified are or should be legitimate: Why should the presence of reasonable alternatives preclude someone's decision to edit the germline of his or her gametes and/or embryo? Can trials really focus only on editing genes that seem to predispose or cause the disease or condition? Why not allow medical or nonmedical enhancement as a form of free speech $?^{75}$ How might long-term follow up be possible, given the difficulty of tracking individuals throughout the lifespan? What does it mean to control societal risks, and who, if anyone, would be accountable if problems were to arise? Which mechanisms might effectively prevent the extension to uses other than preventing a serious disease or condition? And who should pay for them? That part of the NASEM's mission is to "guide the development of federal laws and regulations, improve the effectiveness of government programs, shape the direction of research fields, and inform public knowledge and dialogue ${ }^{, 76}$ underscores the importance of further attention to, and justification for, these considerations.

Despite their value in raising questions and generating dialogue, it is unlikely that any single ethics report or position statement - now or in the future - could address all critical issues raised by heritable genome editing technology (Table 1). Nonetheless, if nations or groups hold strong reasons to promote, stymie, or prohibit certain areas of this research, then authoritative ethics statements could serve as the base upon which to craft national and international law and public policy. The Belmont Report, ${ }^{77}$ Declaration of Helsinki, ${ }^{78}$ and Nuremberg Code $^{79}$ inspired the development and evolution of federal regulations governing the involvement of human subjects in research in the United States. Heritable genome ethics statements might serve as the foundation upon which to update the first two of these important documents and might be employed to inspire additional international laws. The proliferation of dozens of ethics statements seems like a reasonable first step toward solidifying and formalizing the global community's concerns.

Yet given the rapid pace of advancement in this field, it is essential that the discussion advance broadly to explain why certain conclusions could be justified and optimal at this time and how, if at all, they might advance international policymaking and law. The Nuffield Council on Bioethics' first report in 2016 reviewed ethical issues in genome editing, ${ }^{58}$ and later in 2018 the Council will publish another report making recommendations to inform policy and practice. These recommendations will be welcomed but will settle upon a voluminous and often contradictory series of statements gathered from all corners of the globe.

In a recent commentary published in Nature, Janasaoff and Hurlburt claim that the global conversation about heritable genome editing has fallen short of the "cosmopolitan conversation" that is required. ${ }^{80}$ Decision makers about how novel technologies will be used typically split into two camps: pioneering scientists and experts who study how such innovation might disrupt social norms, with little communication between the two camps. ${ }^{80}$ As a remedy, Janasaoff and Hurlburt advocate for a new foundational platform - a "global observatory for gene editing"upon which to engage multiple stakeholders. Deliberations by this observatory would be driven not by scientific research agendas but by the values and priorities of society. The group would consist of "an international network of scholars and organizations similar to those established for human rights and climate change. The network would be dedicated to gathering information from dispersed sources, bringing to the fore perspectives that are often overlooked, and promoting exchange across disciplinary and cultural divides.",80

Many in the international scientific community (and others) have already called for increased public input about moral considerations in heritable genome editing,,$^{1,12-14,17-19,21-37,39-42,44-49,51-59,61,62,64,66-69}$ demonstrating sincere interest and openness to views from outside disciplines. Yet even if the observatory for gene editing proves to be an effective foundation upon which to guide the global community, important questions remain: What does "societal consensus entail," and is it possible and/or desirable? What influence would the observatory's decisions have, and why? Should its decisions be permitted to trump scientific innovation? If so, by what authority? Even if its instantiation would be optimal, the observatory raises just as many, if not more, questions as the statements.

\section{Author Disclosure Statement}

No competing financial interests exist.

\section{References}

1. National Academies of Sciences Engineering and Medicine. Human genome editing: science, ethics, and governance. Washington, DC: The National Academies Press (U.S.). 2017.

2. National Academies of Sciences Engineering and Medicine. News. With stringent oversight, heritable germline editing clinical trials could one day be permitted for serious conditions; non-heritable clinical trials 
should be limited to treating or preventing disease or disability at this time. https://nam.edu/with-stringent-oversight-heritable-germlineediting-clinical-trials-could-one-day-be-permitted-for-seriousconditions-non-heritable-clinical-trials-should-be-limited-to-treatingor-preventing-diseas (last accessed April 14, 2018).

3. Code of Federal Regulations: Research Involving Pregnant Women or Fetuses, 45 C.F.R. Sect 46 (2017).

4. United States Code: Institutional Review Boards; Ethics Guidance Program, 42 U.S. Code Sect 289 (2017).

5. Consolidated Appropriations Act of 2016. www.congress.gov/114/bills/ hr2029/BILLS-114hr2029enr.pdf (last accessed April 14, 2018).

6. Kimmelman J. Ethics of cancer gene transfer clinical research. Methods Mol Biol. 2015;1317:263-285. DOI: 10.1007/978-1-4939-2727-2_15.

7. Committee on the Independent Review and Assessment of the Activities of the NIH Recombinant DNA Advisory Committee, Board on Health Sciences Policy, Institute of Medicine; Lenzi RN, Altevogt BM, Gostin LO, editors. Oversight and review of clinical gene transfer protocols: assessing the role of the Recombinant DNA Advisory Committee. Washington, DC: National Academies Press. 2014.

8. Urnov FD. Genome editing B.C. (Before CRISPR): Lasting lessons from the "Old Testament." CRISPR J. 2018;1:34-46. DOI: 10.1089/crispr.2018.29007.fyu.

9. $\mathrm{Ma} \mathrm{H}$, Marti-Gutierrez N, Park SW, Wu J, et al. Correction of a pathogenic gene mutation in human embryos. Nature. 2017;548:413-419. DOI:

10. Liang $P, X u Y$, Zhang X, Ding C, et al. CRISPR/Cas9-mediated gene editing in human tripronuclear zygotes. Protein Cell. 2015;6:363-372. DOI: 10.1038/nature23305

11. Kang $X$, He $W$, Huang $Y, Y u$, et al. Introducing precise genetic modifications into human 3PN embryos by CRISPR/Cas-mediated genome editing. J Assist Reprod Genet. 2016;33:581-588. DOI: 10.1007/s10815-016-0710-8.

12. Australian Council of Learned Academies. The future of precision medicine. https://acola.org.au/wp/wp-content/uploads/PMED-20180220.pdf (last accessed April 14, 2018).

13. Centre of Genomics and Policy, McGill University and Génome Québec Innovation Centre. Human genome editing: ethical and policy considerations. http://www.genomequebec.com/DATA/PUBLICATION/34_en v Human_Genome_Editing_-_Policy_Brief.pdf (last accessed April 14, 2018).

14. Canadian Institutes of Health Research. Human germline gene editing: points to consider from a Canadian perspective. www.cihr-irsc.gc.ca/e/ documents/sce_human_germline_gene_editing_en.pdf (last accessed April 14, 2018).

15. The Danish Council on Ethics. Statement from the Danish Council on Ethics in genetic modification of future humans: in response to advances in the CRISPR technology. http://www.etiskraad.dk/ /media/ Etisk-Raad/en/Publications/Statement-on-genetic-modification-offuture-humans-2016.pdf (last accessed April 14, 2018).

16. Alliance VITA Solidaires de plus fragiles. New genetic technologies in human beings and human rights. www.alliancevita.org/wp-content/ uploads/2017/04/2017-4-VITA-New-genetic-technologies-in-humanbeings-and-Human-rights-site.pdf (last accessed April 14, 2018).

17. Académie Nationale de Médecine. Genetic editing of human germline cells and embryos. www.academie-medecine.fr/wp-content/uploads/ 2016/05/report-genome-editing-ANM-2.pdf (last accessed April 14, 2018).

18. Institut National de la Santé et de la Recherche Médicale. Ethical issues surrounding CRISPR-Cas9 technology. https://presse.inserm.fr/en/ethical-issuessurrounding-crispr-cas9-technology/24366/ (last accessed April 14, 2018).

19. Deutscher Ethikrat. Germline intervention in the human embryo: German Ethics Council calls for global political debate and international regulation. www.ethikrat.org/files/recommendation-germline-interventionin-the-human-embryo.pdf (last accessed April 14, 2018).

20. Leopoldina Nationale Akademie der Wissenschaften. Ethical and legal assessment of genome editing in research on human cells. https:// www.leopoldina.org/uploads/tx_leopublication/2017_Diskussions papier_GenomeEditing_01.pdf (last accessed April 14, 2018).

21. Berlin-Brandenburg Academy of Sciences and Humanities. Human genome surgery-towards a responsible evaluation of a new technology. www.bbaw.de/publikationen/neuerscheinungen/pdf/BBAW_HumanGenome-Surgery_PDF-A1b-1.pdf (last accessed April 14, 2018).

22. German Stem Cell Network. Moratorium on genetic engineering of the human germline. www.gscn.org/Portals/0/Dokumente/Newsletter/ Moratorium_GSCN_GenEd_EN.pdf (last accessed April 14, 2018).

23. Hellenic National Bioethics Commission. Recent developments in human genome modification: genome editing. www.bioethics.gr/
images/pdf/GNOMES/OPINION__gene\%20editing_Final_EN.pdf (last accessed April 14, 2018).

24. India Council of Medical Research. National ethical guidelines for biomedical and health research involving human participants. http:// icmr.nic.in/guidelines/ICMR_Ethical_Guidelines_2017.pdf (last accessed April 14, 2018).

25. Science Council of Japan. Genome editing technology in medical sciences and clinical applications in Japan. www.scj.go.jp/ja/info/kohyo/ pdf/kohyo-23-t251-1-en.pdf (last accessed April 14, 2018).

26. De Wert G, Pennings G, Clarke A, Eichenlaub-Ritter U, et al. Human germline gene editing: Recommendations of ESHG and ESHRE. Eur J Hum Genet. 2018; Jan 12 [Epub ahead of print]. DOI: 10.1038/s41431017-0076-0.

27. De Wert G, Heindryckx B, Pennings G, Clarke A, et al. Responsible innovation in human germline gene editing: Background document to the recommendations of ESHG and ESHRE. Eur J Hum Genet. 2018; Jan 12 [Epub ahead of print]. DOI: 10.1038/s41431-017-0077-z.

28. Ormond Ke, Mortlock Dp, Scholes Dt, Bombard Y, et al. Human germline genome editing. Am J Hum Genet. 2017; 101:167-176. DOI: 10.1016/ j.ajhg.2017.06.012.

29. Chneiweiss H, Hirsch F, Montoliu L, Muller Am, et al. Fostering responsible research with genome editing technologies: a European perspective. Transgenic Res. 2017:26:70--713. DOI: 10.1007/s11248-017-0028-z.

30. Council of Europe. The use of new technologies in human beings. http:// semanticpace.net/tools/pdf.aspx?doc=aHR0cDovL2Fzc2VtYmx5 LmNvZS5pbnQvbncveG1sL1hSZWYvWDJILURXLWV4dHIuYXNwP2Zpb GVpZD0yNDlyOCZsYW5nPUVO\&xsl=aHROcDovL3NIbWFudGljcGFjZS 5uZXQvWHNsdC9QZGYvWFJIZi1XRC1BVC1YTUwyUERGLnhzbA== \&xsltparams=ZmlsZWIkPTIOMjl4 (last accessed April 14, 2018).

31. European Academies Science Advisory Council. Genome editing: scientific opportunities, public interests and policy options in the European Union. www.knaw.nl/shared/resources/internationaal/bestanden/easacreport-31-on-genome-editing-20170323 (last accessed April 14, 2018).

32. Howard HC, van El CG, Forzano F, et al. One small edit for humans, one giant edit for humankind? Points and questions to consider for a responsible way forward for gene editing in humans. Eur J Hum Genet. 2017;26:1-11. DOI: 10.1038/s41431-017-0024-z.

33. Federation of European Academies of Medicine. The application of genome editing in humans. www.feam.eu/wp-content/uploads/HumanGenome EditingFEAMPositionPaper2017.pdf (last accessed April 14, 2018).

34. European Group on Ethics in Science and New Technologies. Statement on gene editing. https://ec.europa.eu/research/ege/pdf/gene_editing_ ege_statement.pdf (last accessed April 14, 2018).

35. Federation of European Academies of Medicine. Human genome editing in the EU. www.interacademies.org/File.aspx?id=31273 (last accessed April 14, 2018).

36. Latin America Workshop CRISPR/CAS9. Fostering global responsible research with CRISPR-Cas9. www.inserm.fr/en/research-inserm/ethics/ inserm-ethics-committee-cei/ethics-committee-workshops/fosteringresponsible-research-with-crispr-cas9-paris (last accessed April 14, 2018).

37. Friedmann T, Jonlin Ec, King Nmp, Torbett Be, et al. ASGCT and JSGT joint position statement on human genomic editing. Mol Ther. 2015:23:1282. DOI: $10.1038 / \mathrm{mt} .2015 .118$.

38. European Society of Gene and Cell Therapy. Editing our future; Facilitating dialogue on the use of gene-editing to modify human embryos. http://www.esgct.eu/Content/Media/ESGCT\%20FSGT\%20Congress\%20 and\%20Debate\%20Press\%20Release.pdf (last accessed April 14, 2018).

39. The Hinxton Group. Statement on genome editing technologies and human germline genetic modification. www.hinxtongroup.org/ hinxton2015_statement.pdf (last accessed April 14, 2018).

40. Matthews DJH, Lowell-Badge R, Chan S, et al. (2015). CRISPR: A path through the thicket. Nature. 2015:527;159-161. DOI: 10.1038/527159a.

41. CRISPR Therapeutics. Joint statement of Intellia Therapeutics \& CRISPR Therapeutics: Position regarding human germline gene editing. http:// crisprtx.com/1130\%20CRISPR\%20-\%20INTELLIA\%20CRISPR\% 20TX\%20POSITION\%20STATEMENT.pdf (last accessed April 14, 2018).

42. International Bioethics Committee, United Nations Educational, Scientific and Culture Organization. Report of the IBC on updating its reflection on the human genome and human rights. http://unesdoc.unesco.org/ images/0023/002332/233258E.pdf (last accessed April 14, 2018).

43. International Institute of Advanced Studies Center for Applied Philosophy \& Ethics. Toward constructing an interdisciplinary platform for 
bioethics. www.cape.bun.kyoto-u.ac.jp/wp-content/uploads/2014/03/ Report_gene_editing_IIAS_20151122.pdf (last accessed April 14, 2018).

44. International Society for Stem Cell Research. The ISSCR statement on human genome germline modification. http://www.isscr.org/docs/ default-source/policy-documents/isscr-statement-on-human-germlinegenome-modification.pdf?sfvrsn=0 (last accessed April 14, 2018)

45. The National Academies of Sciences, Engineering, and Medicine. On Human Genome Editing: International Summit Statement. Press release. http://www8.nationalacademies.org/onpinews/newsitem .aspx?RecordID=12032015a (last accessed April 14, 2018).

46. Commission on Genetic Modification and the Health Council of the Netherlands. Editing human DNA: Moral and social implications of germline genetic modification. https://www.cogem.net/showdownload.cfm? objectld=70887ADF-994A-9B52-0E78FF87990B86EA\&objectType $=$ mark.hive.contentobjects.download.pdf (last accessed April 14, 2018).

47. The Royal Netherlands Academy of Arts and Sciences. Genome editing: Position paper of the Royal Academy of Arts and Sciences. www.knaw .nl/shared/resources/actueel/publicaties/pdf/genome-editing-positionpaper-knaw-november-2016 (last accessed April 14, 2018).

48. Royal Society Te Apārangi Gene Editing Panel. Gene editing in a healthcare context. https://royalsociety.org.nz/assets/Uploads/Gene-editingin-healthcare-technical-paper.pdf (last accessed April 14, 2018).

49. Royal Society Te Apārangi. The use of gene editing in healthcare. https:// royalsociety.org.nz/assets/Uploads/The-use-of-gene-editing-inhealthcare-discussion-paper.pdf (last accessed April 14, 2018).

50. The Norwegian Biotechnology Advisory Board recommends allowing human germ line editing for basic research [press release]. http://www .bioteknologiradet.no/2016/01/the-norwegian-biotechnology-advisoryboard-recommends-allowing-human-germ-line-editing-for-basic-research/ (last accessed April 14, 2018). www.bioteknologiradet.no/filarkiv/2015/ 12/Uttalelse_genmodifisering.pdf (last accessed April 14, 2018).

51. Bioethics and Law Observatory of the University of Barcelona; Document on bioethics and gene editing in humans. www.publicacions.ub.edu/ refs/observatoriBioEticaDret/documents/08543.pdf (last accessed April 14, 2018).

52. The Academy of Medical Sciences. The Academy of Medical Sciences' response to the Nuffield Council on Bioethics 'Genome editing and human reproduction' [press release]. https://acmedsci.ac.uk/filedownload/89659337 (last accessed April 14, 2018).

53. Genetic Alliance UK and the Progress Educational Trust Supported by Wellcome Trust. Basic understanding of genome editing: the report. https://pet.ultimatedb.net/res/org10/Reports/genomeediting_ recommendations.pdf (last accessed April 14, 2018).

54. House of Commons Science and Technology Committee. Genomics and genome-editing: future lines of inquiry. https://publications .parliament.uk/pa/cm201617/cmselect/cmsctech/854/854.pdf (last accessed April 14, 2018).

55. The Royal Society. Potential and risks of recent developments in biotechnology: A speech by Venki Ramakrishnan President of the Royal Society. https://royalsociety.org/ /media/news/2017/venki-ramakrishnan-aaasspeech-gene-tech-18-02-17.pdf?la=en-GB (last accessed April 14, 2018).

56. Cambridge Public Policy SRI. Planning for the future of gene editing. www.publicpolicy.cam.ac.uk/pdf/stem-cells-report (last accessed April 14, 2018).

57. The Muslim Council of Britain. Muslim Council of Britain Response to Nuffield Council on Bioethics with respect to genome editing. http://archive.mcb .org.uk/wp-content/uploads/2015/12/MCB-Response-to-the-NuffieldCouncil-on-Bioethics-with-Respect-to-Genome-Editing.pdf (last accessed April 14, 2018).

58. Nuffield Council on Bioethics. Genome editing: An ethical review. https://acmedsci.ac.uk/file-download/89659337 (last accessed April 14, 2018).

59. Academy of Medical Sciences, Association of Medical Research Charities Biotechnology and Biological Science Research Council, Cancer Research UK; Medical Research Council; Progress Educational Trust; Wellcome Trust; Wellcome Trust Sanger Institute. Genome editing in human cells. https://wellcome.ac.uk/sites/default/files/wtp059707.pdf (last accessed April 14, 2018).

60. Alliance for Regenerative Medicine. The alliance for regenerative medicine issues statement in response to reports of first use of genome editing technology in human embryos in the U.S. https:// alliancerm.org/press/alliance-regenerative-medicine-issues-statementresponse-reports-first-use-gene-editing (last accessed April 14, 2018).

61. American College of Medical Genetics and Genomics. Genome editing in clinical genetics, points to consider: A statement of the American College of Medical Genetics and Genomics. www.acmg.net/docs/ FINAL_CRISPR.pdf (last accessed April 14, 2018)

62. Biotechnology Innovation Organization. Position statement on human genome editing. www.bio.org/GenomeEditing (last accessed April 14, 2018).

63. Merck. Genome editing technology_principle. https://www.emdgroup .com/content/dam/web/corporate/non-images/company/responsibility/ us/regulations-and-guidelines/genome-editing-principle_US.pdf (last accessed April 14, 2018).

64. California Institute for Regenerative Medicine. Draft recommendations for the CIRM scientific and medical accountability standards working group (SWG) workshop on human gene editing. https://www.cirm.ca .gov/sites/default/files/files/board_meetings/Genome\%20Editing\% 20Workshop\%20Draft\%20Summary_3_22_16_Revised_6_8_2016.pdf (last accessed April 14, 2018).

65. National Society of Genetic Counselors. Human germline editing [press release]. www.nsgc.org/p/bl/et/blogaid=826 (last accessed April 14, 2018).

66. American Society for Investigative Pathology. Position statement of the American Society for investigative pathology on manipulation of the human genome. www.asip.org/SciencePolicy/documents/ASIP.Human .Genome.Manipulation.November2015.pdf (last accessed April 14, 2018).

67. Baltimore $D$, Berg $P$, Botchan $M$, et al. Biotechnology. A prudent path forward for genomic engineering and germline gene modification. Science 2015;348:36-38. DOI: 10.1126/science.aab1028.

68. Center for Genetics and Society. Open letter calls for prohibition on reproductive human germline modification. www.genetics andsociety.org/internal-content/open-letter-calls-prohibitionreproductive-human-germline-modification (last accessed April 14, 2018).

69. Editas Medicine. Editas Medicine comments in connection with International Summit on Human Gene Editing [press release]. http:// ir.editasmedicine.com/phoenix.zhtml?c=254265\&p=irol-news Article\&ID $=2125234$

70. Collins F. Statement on NIH funding of research using gene-editing technologies in human embryos [press release]. www.nih.gov/about-nih/whowe-are/nih-director/statements/statement-nih-funding-researchusing-gene-editing-technologies-human-embryos (last accessed April 14, 2018).

71. Holdrege $C$, Nature Institute. Manipulating the genome of human embryos: some unforeseen effects. http://natureinstitute.org/txt/ch/ human_gmo_embryo.php (last accessed April 14, 2018).

72. Society for Developmental Biology. Position statement from the Society for Developmental Biology on genomic editing in human embryos. www.sdbonline.org/position_statements (last accessed April 14, 2018).

73. Holdren J. Note on genome editing. The White House [press release]. https://obamawhitehouse.archives.gov/blog/2015/05/26/notegenome-editing (last accessed April 14, 2018).

74. Church $\mathrm{G}$. Compelling reasons for repairing human germlines. N Engl J Med 2017;377:1909-1911. DOI: 10.1056/NEJMp1710370.

75. U.S. CONST. amend. 1.

76. The National Academies of Sciences, Engineering, and Medicine. Advising the Nation. Advancing the Discussion. Connecting New Frontiers. www.nationalacademies.org/brochure/index.html (last accessed April 14, 2018).

77. U.S. National Commission for the Protection of Human Subjects of Biomedical and Behavioral Research. The Belmont report: ethical principles and guidelines for the protection of human subjects of research. Bethesda, MD \& Washington, DC: U.S. Government Printing Office 1978.

78. World Medical Association Assembly. World Declaration of Helsinki. The Ethical Principles for Medical Research Involving Human Subjects. www.wma.net/policies-post/wma-declaration-of-helsinki-ethicalprinciples-for-medical-research-involving-human-subjects/ (last accessed April 14, 2018).

79. The Nuremberg Code. https://history.nih.gov/research/downloads/ nuremberg.pdf (last accessed April 14, 2018).

80. Jasanoff S, Hurlburt JB. A global observatory for gene editing. Nature. 2018;555:435-437. DOI: 1038/d41586-018-03270-w. 